\title{
Ethical vs. Unethical Advertisements: Evaluation and Recall: An Abstract
}

\author{
Kevin Lehnert and Mark Kubik
}

\begin{abstract}
This study begins to address the role of those advertisements with an ethical or unethical message. Past research has focused on the role of ethical products or deceptive advertising messages based upon product/service attributes. This research looks at another form of ethical advertising, the role of the message that is independent of the product/service. Those associations of this branded message can impact consumer response and their social judgment of the ethicality of the advertisement. Through an experimental design, with a one-week delay, we note that there are no recall effects based upon the ethical valence of the ad. Those ads judged as unethical were also more negatively evaluated, but the overall evaluation of the ad decreased for both ethical and unethical ads over time. Implications and future research are discussed.
\end{abstract}

References Available Upon Request

K. Lehnert $(\bowtie) \cdot$ M. Kubik

Grand Valley State University, Grand Rapids, MI, USA

e-mail: lehnertk@gvsu.edu; kubikma@gvsu.edu 